\title{
Supplemental Materials
}

Psychometric Properties of the Posttraumatic Diagnostic Scale for DSM-5 (PDS-5)

by E. B. Foa et al., 2015, Psychological Assessment

http://dx.doi.org/10.1037/pas0000258 


\section{PTSD Diagnostic Scale for DSM-5}

(PDS-5)

\section{Participant ID}

\section{Date}

\section{TRAUMA SCREEN}

Have you ever experienced, witnessed, or been repeatedly confronted with any of the following:

(Check all that apply)

Serious, life threatening illness (heart attack, etc.)

$\square$ Physical Assault (attacked with a weapon, severe injuries from a fight, held at gunpoint, etc.)

$\square$ Sexual assault (rape, attempted rape, forced sexual act with a weapon, etc.)

$\square$ Military combat or Ived in a war zone

$\square$ Child abuse (severe beatings, sexual acts with someone 5 years older than you, etc.)

Accident (serious injury or death from a car, at work, a house fire, etc.)

$\square$ Natural disaster (severe hurricane, flood, earthquake, etc.)

Other trauma (Please describe briefly):

$\square$ None

*** If NONE, please STOP and return this questionnaire ***

If you marked any of the above items, which single traumatic experience is on your mind and currently bothers you the most:

(Check only one)

$\square$ Serious, life threatening illness (heart atack, etc.)

Physical Assault (attacked with a weapon, severe injuries from a fight, held at gunpoint, etc.)

$\square$ Sexual assault (rape, attempted rape, forced sexual act with a weapon, etc.)

$\square$ Military combat or lived in a war zone

$\square$ Child abuse (severe beaings, sexual acts with someone 5 years older than you, etc.)

Accident (serious injury or death from a car, at work, a house fire, etc.)

$\square$ Natural disaster (severe hurricane, flood, earthquake, etc.)

Other trauma (Please describe briefly): 
Instructions: Below is a list of problems that people sometimes have after experiencing a traumatic event. Write down the most distressing traumatic event that you checked on the last page:

Please read each statement carefully and circle the number that best describes how often that problem has been happening and how much it upset you over THE LAST MONTH. Rate each problem with respect to the traumatic event that you wrote above.

For example, if you've talked to a friend about the trauma one time in the past month, you would respond like this: (because one time in the past month is less than once a week)

Talking to other people about the trauma

$\begin{array}{ccccc}0 & 1 & 2 & 3 & 4 \\ \text { Not at all } & \begin{array}{c}\text { Once a week or } \\ \text { less/a little }\end{array} & \begin{array}{c}2 \text { to } 3 \text { times a } \\ \text { week/somewhat }\end{array} & \begin{array}{c}4 \text { to } 5 \text { times a } \\ \text { week/very much }\end{array} & \begin{array}{c}6 \text { or more times a } \\ \text { week/severe }\end{array}\end{array}$

1. Unwanted upsetting memories about the trauma

0

Not at all
1

Once a week or less/a little
2

2 to 3 times a

week/somewhat
3

4 to 5 times a

week/very much
4

6 or more times a week/severe

2. Bad dreams or nightmares related to the trauma

$$
0
$$

Not at all

\section{1}

Once a week or less/a little
2

2 to 3 times a week/somewhat
3

4 to 5 times a week/very much
4

6 or more times a week/severe

3. Reliving the traumatic event or feeling as if it were actually happening again

0

Not at all
1

Once a week or

less/a little
2

2 to 3 times a

week/somewhat
3

4 to 5 times a week/very much
4

6 or more times a week/severe

\section{Feeling very EMOTIONALLY upset when reminded of the trauma}

0

Not at all
1

Once a week or less/a little
2

2 to 3 times a

week/somewhat
3

4 to 5 times a week/very much
4

6 or more times a week/severe

5. Having PHYSICAL reactions when reminded of the trauma (for example, sweating, heart racing)

0

Not at all
1

Once a week or less/a little
2

2 to 3 times a week/somewhat
3

4 to 5 times a week/very much
4

6 or more times a week/severe

6. Trying to avoid thoughts or feelings related to the trauma

$$
0
$$

Not at all
1

Once a week or less/a little
2

2 to 3 times a

week/somewhat
3

4 to 5 times a

week/very much
4

6 or more times a

week/severe

7. Trying to avoid activities, situations, or places that remind you of the trauma or that feel more dangerous since the trauma

$\begin{array}{ccc}0 & 1 & 2 \\ \text { Not at all } & \begin{array}{c}\text { Once a week or } \\ \text { less/a little }\end{array} & 2 \text { to } 3 \text { times a } \\ \text { week/somewhat }\end{array}$

3

4 to 5 times a week/very much
4

6 or more times a week/severe 
8. Not being able to remember important parts of the trauma

0

Not at all
1

Once a week or less/a little

\section{2}

2 to 3 times a

week/somewhat
3

4 to 5 times a week/very much
4

6 or more times a week/severe

9. Seeing yourself, others, or the world in a more negative way (for example "I can't trust people," "I'm a weak person”)

0

Not at all
1

Once a week or

less/a little

\section{2}

2 to 3 times a

week/somewhat
3

4 to 5 times a week/very much
4

6 or more times a

week/severe

10. Blaming yourself or others (besides the person who hurt you) for what happened

0

Not at all
1

Once a week or less/a little
2

2 to 3 times a

week/somewhat
3

4 to 5 times a week/very much
4

6 or more times a week/severe

11. Having intense negative feelings like fear, horror, anger, guilt or shame

0

Not at all
1

Once a week or less/a little
2

2 to 3 times a
week/somewhat
3

4 to 5 times a week/very much
4

6 or more times a week/severe

12. Losing interest or not participating in activities you used to do

0

Not at all
1

Once a week or less/a little

\section{2}

2 to 3 times a week/somewhat
3

4 to 5 times a week/very much
4

6 or more times a week/severe

\section{Feeling distant or cut off from others}

0

Not at all

\section{1}

Once a week or less/a little
2

2 to 3 times a week/somewhat
3

4 to 5 times a week/very much
4

6 or more times a week/severe

14. Having difficulty experiencing positive feelings

0

Not at all

\section{1}

Once a week or less/a little
2

2 to 3 times a week/somewhat
3

4 to 5 times a week/very much
4

6 or more times a week/severe

15. Acting more irritable or aggressive with others

0

Not at all
1

Once a week or less/a little
2

2 to 3 times a week/somewhat
3

4 to 5 times a week/very much
4

6 or more times a week/severe

16. Taking more risks or doing things that might cause you or others harm (for example, driving recklessly, taking drugs, having unprotected sex)

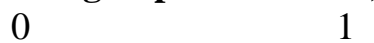

Not at all
1

Once a week or less/a little
2

2 to 3 times a week/somewhat
3

4 to 5 times a week/very much
4

6 or more times a week/severe

17. Being overly alert or on-guard (for example, checking to see who is around you, being uncomfortable with your back to a door)

0

Not at all
1

Once a week or less/a little
2

2 to 3 times a week/somewhat
3

4 to 5 times a week/very much
4

6 or more times a week/severe 
18. Being jumpy or more easily startled (for example when someone walks up behind you)

$\begin{array}{ccccc}0 & 1 & 2 & 3 & 4 \\ \text { Not at all } & \begin{array}{c}\text { Once a week or } \\ \text { less/a little }\end{array} & 2 \text { to } 3 \text { times a } & 4 \text { to } 5 \text { times a } & 6 \text { or more times a } \\ & \text { week/somewhat } & \text { week/very much } & \text { week/severe }\end{array}$

19. Having trouble concentrating

0

Not at all
1

Once a week or less/a little
2

2 to 3 times a week/somewhat
3

4 to 5 times a week/very much
4

6 or more times a week/severe

20. Having trouble falling or staying asleep

0

Not at all
1

Once a week or less/a little
2

2 to 3 times a week/somewhat
3

4 to 5 times a week/very much
4

6 or more times a week/severe

\section{DISTRESS AND INTERFERENCE}

21. How much have these difficulties been bothering you?

0

Not at all
1

Once a week or less/a little
2

2 to 3 times a week/somewhat
3

4 to 5 times a week/very much
4

6 or more times a week/severe

22. How much have these difficulties been interfering with your everyday life (for example relationships, work, or other important activities)?

0

Not at all
1

Once a week or less/a little
2

2 to 3 times a week/somewhat
3

4 to 5 times a week/very much
4

6 or more times a week/severe

\section{SYMPTOM ONSET AND DURATION}

23. How long after the trauma did these difficulties begin? [circle one]
a. Less than 6 months
b. More than 6 months

24. How long have you had these trauma-related difficulties? [circle one]
a. Less than 1 month
b. More than 1 month 